\title{
Urinary symptoms and sexual dysfunction among Italian men: The results of the \#Controllati survey
}

\author{
Vincenzo Mirone ${ }^{1}$, Roberto Carone ${ }^{2}$, Giuseppe Carrieri ${ }^{3}$, Elisabetta Costantini ${ }^{4}$, Giuseppe Morgia ${ }^{5}$, \\ Giuseppe Mario Ludovico ${ }^{6}$, Donata Villari ${ }^{7}$, Fabio Parazzini ${ }^{8}$ on behalf of the \#Controllati study group ${ }^{*}$ \\ ${ }^{1}$ Università degli Studi di Napoli Federico II, UOC di Urologia della A.O.U. Federico II, Napoli, Italy; \\ ${ }^{2}$ Università degli Studi di Torino, Struttura Complessa di Neuro-Urologia A.O.U. Città della Salute e della Scienza, Torino, Italy; \\ ${ }^{3}$ Dipartimento Nefro/Urologico Clinica Urologica e Centro Trapianti di Rene, Università degli Studi di Foggia, Italy; \\ ${ }^{4}$ Sezione di Urologia Femminile, Funzionale e di Chirurgia Urologica Mini-invasiva. Dipartimento di Scienze Chirurgiche \\ e Biomedicali, Università di Perugia, Italy; \\ ${ }^{5}$ Università degli Studi di Catania, Presidio Ospedaliero Policlinico, Catania, Italy; \\ 6 Struttura Complessa Urologia, Ospedale "Miulli", Acquaviva delle Fonti, Italy; \\ ${ }^{7}$ Università degli Studi di Firenze, SOD Chirurgia Urologica Mini-invasiva e dei Trapianti, Azienda Mista Universitaria \\ Ospedaliera, Careggi, Italy; \\ ${ }^{8}$ Dipartimento di Scienze Cliniche e di Comunità, Università di Milano, IRCCS Policlinico Milano, Italy.
}

\begin{abstract}
Summary Objective: Prevention may improve the quality of life and sexual and reproductive health. To improve prevention require a comprehensive research approach that examines the frequency and risk factors for urologic conditions. In June 2016 the Italian Urologic Society coordinated a preventive initiative : the $1^{\text {st }}$ Week of Male Urologic Prevention "\#Controllati".

Material and methods: During the $1^{\text {st }}$ Week of Male Urologic Prevention "\#Controllati", men aged 18 years or more were invited to attend participating urologic centers for a free of charge visit for counseling about urologic or andrologic conditions. Each participating man underwent a physical examination. Further he was asked about his a medical history and about his urologic symptoms, sexual activity and possible related problems.

Results: Data were collected in 81 centers: 2380 men answered the questionnaire. A total of 1226 subjects participating in the study reported one or more urinary symptom [51.5\% (IC 95\% 48.9\%-54.5\%)]. The risk of any urinary symptoms increased with age: in comparison with men aged $<=30$ years or less the risk of any urinary symptoms was $2.31,2.92,5.12,7.82$ and 17.02 respectively in the class age $31-40,41-50,51-60,61-70$ and $>=71$. Overweight/obese men were at increased risk of any urinary symptoms [OR1.35 (95\% CI 1.12-1.64)]. 27.2\% (IC 95\% overall 25.2\% $-29.3 \%$ ) of the subjects had at least a sexual disorder (erectile dysfunction, premature ejaculation, hypoactive sexual desire). The erectile dysfunction and hypoactive sexual desire increased with age, but premature ejaculation tended to be higher among younger aged men aged 40 years or more. Current any urinary symptoms [OR 1.85 (CI 1.40-2.43)], hypertension [OR 1.66 (95\% CI 1.21-2.26) and diabetes (OR 2.37 (95\% CI 1.45-3.88)] increased the risk of erectile dysfunction.

Conclusions: This large survey gives a picture of the burden of the more frequent urologic conditions offering useful information in order to focus preventive campaign.
\end{abstract}

KEY WORDS: Risk factors; Urinary symptoms; Erectile dysfunction; Premature ejaculation.

Submitted 16 March 2017; Accepted 21 March 2017

\section{INTRODUCTION}

Urologic diseases are common among men, leading to significant economic, quality of life and public health issues (1). For example, the reported prevalence of lower urinary tract symptoms (LUTS) is about 50\% (2) and of erectile dysfunction $12 \%$ (3).

Among Italian men, the lifelong risk of urologic cancer (prostatic bladder and kidney cancer) is about one out of ten (4). The burden of urologic diseases in men will increase as the population ages, and risk factors for LUTS, including diabetes and obesity, remain highly prevalent (5). Adequate prevention, especially in the field of urology, made in young, adult and advanced age, significantly reduces the frequency of cancer (prostate, kidney, bladder and testicle), allowing also an early diagnosis and timely treatment, and benign disease (urolithiasis, benign prostate hyperplasia and prostatitis, male infertility and sexual dysfunction), that can determine, if neglected, a reduction in the quality of life, and sexual and reproductive health damage.

Otherwise, to improve prevention requires a comprehensive research approach that examines the frequency and risk factors for urologic conditions.

In June 2016 the Italian Urologic Society (SIU) coordinated a huge preventive initiative: the $1^{\text {st }}$ Week of Male Urologic Prevention "\#Controllati". In this paper, we present the results of the initiative, with a special focus on LUTS and sexual dysfunction.

\section{Methods}

During the $1^{\text {st }}$ Week of Male Urologic Prevention "\#Controllati" (June 2016), men aged 18 years or more were invited to attend participating urologic centers for a free of charge visit for counselling about urologic or andrologic conditions. A pamphlet inviting men for a free of charge check-up and listing participating centers was left in chemists and general practitioners' waiting rooms and 
included in two weekly national journals; an advertising campaign was set in the press and broadcast media.

Each participating man underwent a physical examination. Further he was asked about his a medical history and about his urologic symptoms, sexual activity and possible related problems. Data were recorded with a simple questionnaire used by all centers.

The first section, about age, marital, educational and professional status, weight, height, family history of prostatic cancer was completed by the patient. History of hypertension, diabetes and other medical conditions, and the findings of the clinical examination, were recorded by the physician. Erectile function was assessed by asking men about their sexual performance: erectile dysfunction (ED) was diagnosed according to the definition of the NIH Consensus Development Panel (6), when a man was consistently unable to attain or maintain a penile erection sufficient for satisfactory sexual performance.

A man was diagnosed as suffering from premature ejaculation (PE) if he had "persistent or recurrent ejaculation with minima sexual stimulation before, or shortly after penetration, and before the person wishes" according to the categorization of the American Psychiatric Association.

Patients were directly asked about the presence of this disorder during the visit.

The 2002 ICS definitions were used for frequency, nocturia, urgency, dysuria (intermittency, slow stream, straining, terminal dribble, postmicturition dribble) incomplete emptying (7). A total of 181 centres participate to the initiative, 70 in the North, 45 in the center and 66 in the South of Italy. However, epidemiological data were collected in 81 centers for a total of 2380 men who filled the questionnaire [mean number for center 29 (SD 21), median 25 (interquartile range 24-40)].

Mean (standard deviation, SD), median (range) or frequency (percent, \%) were computed as appropriate. Were also calculated where appropriate confidence limits at $95 \%$ of the proportions.

Finally, we ran an analysis on the risk factors for sexual dysfunction (separately for ED and PE) and urinary disorders. Odds ratios (OR), and the corresponding 95\% confidence intervals $(\mathrm{CI})$, were derived using unconditional multiple logistic regression, fitted by the method of maximum likelihood, in which the dependent variable was the presence (case) or absence (control) of the condition and the independent ones were the exposures considered in the analysis. We included in the model potential co-variates considered as categorical variables (8). The terms included in the model are indicated in the footnotes of the Tables.

\section{RESULTS}

The general characteristics of study subjects are shown in Table 1: the mean age was 53.6 years (DS 11.5, median age 53 years, range 18-87). The most frequent class age was 41 to 50 years (31.09\%).

The mean body mass index (BMI) was 26.0 (DS 3.6) and the median 25.5.

Most participants were ever married (70.1\%).

The $13.2 \%$ of subjects reported a diagnosis of hypertension and $3.7 \%$ of diabetes. A family history of prostatic cancer was reported in $9.8 \%$ of subjects.
Frequency of PSA test screening and semen analysis A total of 1291 men $(54.2 \%, 95 \%$ CI $51.3 \%-57.3 \%)$ of the study subjects reported PSA testing. Considering subjects aged 70 years or more, this percentage increased to $84.9 \%$ (95\% CI $71.9 \%-99.5 \%$ ).

Overall, 325 men reported a least one semen analysis in life (13.7\%, 95\% CI 12.2-15.1\%) (Table 2).

\section{Frequency of and risk factors for urinary symptoms}

A total of 1226 subjects participating in the study reported one or more urinary symptom $(51.5 \%$, CI 95\% 48.9\%-54.5\%). The most commonly reported urinary symptom was nocturia, in age groups 50 or more, whereas in younger age groups frequency was the most reported (Table 3).

\section{Table 1.}

Characteristics of study subjects.

\begin{tabular}{|l|c|c|}
\hline & N & $\%$ \\
\hline Age (years) & & \\
$31-40$ & 60 & 2.6 \\
$41-50$ & 171 & 7.5 \\
$51-60$ & 740 & 32,3 \\
$61-70$ & 679 & 29.7 \\
$\geq 71$ & 467 & 20.4 \\
\hline Marital status & 172 & 7.5 \\
\hline Never married & 497 & \\
Married & 1668 & 75.8 \\
Divorced/widower & 36 & 1.6 \\
\hline BMI (kg/m ${ }^{2}$ ) & 877 & \\
\hline$<25.0$ & 886 & 44.1 \\
25.0 -29.9 & 225 & 11.3 \\
$\geq 30.0$ & & \\
\hline Hystory of & 314 & 13.2 \\
Hyperthension (yes) & 87 & 3.7 \\
Diabetes (yes) & 232 & 9.8 \\
Family history of prostatic cancer (yes) & \multicolumn{2}{|l}{} \\
\hline Sometimes, the sums do not add up the total due to missing values \\
\hline
\end{tabular}

Table 2.

Subjects reporting one or more PSA testing and semen analysis in life in strata of age.

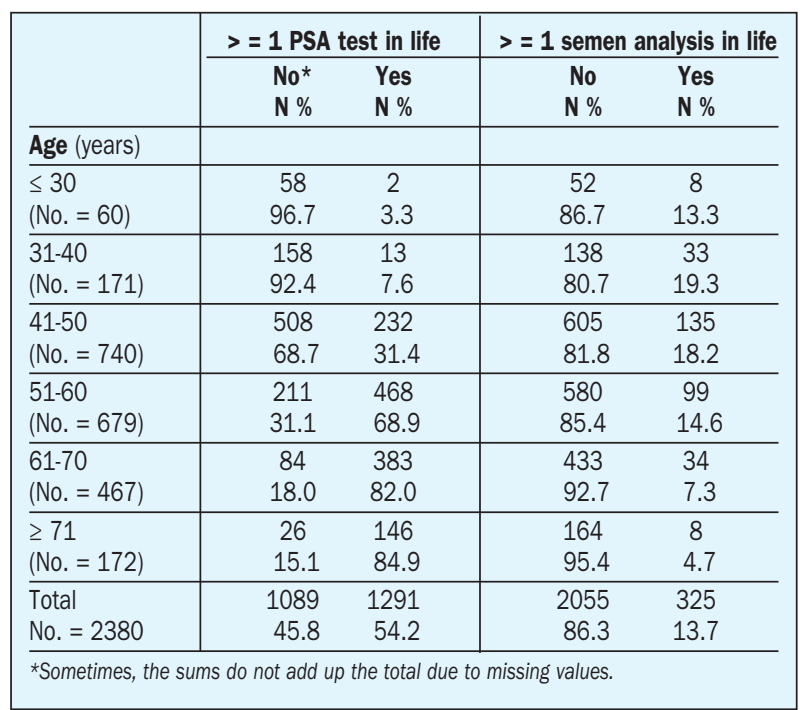


Table 3.

Frequency of urinary symptoms according to age.

\begin{tabular}{|l|c|c|c|c|c|c|}
\hline & Nocturia & Dysuria & $\begin{array}{c}\text { Incomplete } \\
\text { emptying }\end{array}$ & Urgency & Frequency & $\begin{array}{c}\text { Any } \\
\text { symptom }\end{array}$ \\
\hline & $\mathbf{N} \%$ & $\mathbf{N} \%$ & $\mathbf{N} \%$ & $\mathbf{N} \%$ & $\mathbf{N} \%$ & $\mathbf{N} \%$ \\
\hline Age (years) & & & & & & \\
\hline$\leq 30$ & 1 & 4 & 1 & 3 & 3 & 9 \\
(No. $=60)$ & 1.7 & 6.7 & 1.7 & 5.0 & 5.0 & 15.0 \\
\hline $31-40$ & 16 & 20 & 13 & 12 & 25 & 53 \\
(No. =171) & 9.4 & 11.7 & 7.6 & 7.0 & 14.6 & 31.0 \\
\hline $41-50$ & 101 & 88 & 85 & 78 & 90 & 282 \\
(No. =740) & 13.7 & 11.9 & 11.5 & 10.5 & 12.2 & 38.1 \\
\hline $51-60$ & 174 & 116 & 139 & 111 & 125 & 378 \\
(No. =679) & 25.6 & 17.1 & 20.5 & 16.4 & 18.4 & 55.7 \\
\hline $61-70$ & 189 & 81 & 119 & 94 & 104 & 317 \\
(No. =467) & 40.5 & 17.3 & 25.5 & 20.1 & 22.3 & 67.9 \\
\hline$\geq 71$ & 89 & 46 & 59 & 47 & 51 & 141 \\
(No. =172) & 51.7 & 26.7 & 34.3 & 27.3 & 29.7 & 82.0 \\
\hline Total & 587 & 375 & 428 & 350 & 409 & 1226 \\
No. =2380 & 24.7 & 15.8 & 18.1 & 14.7 & 17.2 & 51.5 \\
\hline Sometimes, the sums do not add up the total due to missing values. \\
\hline
\end{tabular}

We analyzed risk factors for any urinary disorders: the results of the analysis are presented in Table 4 . The risk of any urinary symptoms increased with age: in comparison with men aged $<=30$ years or less the risk of any urinary symptoms was $2.31,2.92,5.12,7.82$ and 17.02 respectively in the age classes $31-40,41-50,51-60,61-$ 70 and $>=71$.

Overweight/obese men were at increased risk of any urinary symptoms (OR 1.35, 95\% CI 1.12-1.64).

Further, any current sexual dysfunction was associated with an increased risk of any urinary symptoms (OR1.60. 95\% CI 1.29-1.98).

Analyzing the association of overweight/obesity and any current sexual dysfunction separately for the various urinary symptoms, we observed similar results.

\section{Frequency and risk factors}

of sexual dysfunction

Table 5 shows the distribution of study subjects in strata of age according to the presence of sexual dysfunction (erectile dysfunction, premature ejaculation, hypoactive sexual desire).

$27.2 \%$ (IC $95 \%$ overall $25.2 \%-29.3 \%$ ) of the subjects had at least a sexual disorder. The rate was 30.0\% (CI $95 \% 18.3 \%-46.5 \%)$ in 30 or less, then slightly decrease in group 31-50 and increased in older age groups, being $41,9 \%$ in the men aged $>=71$ years.

The erectile dysfunction and hypoactive sexual desire increased with age, but premature ejaculation tended to be higher among younger aged men aged 40 years or more.

$11.9 \%$, (44, \% 95\% CI 8.7\% -15.8\%) of men reporting erectile dysfunction were currently treated for the condition (data not shown in Table).

We computed risk factors for sexual dysfunction separately for premature ejaculation and erectile dysfunction. The results of the analysis are presented in Table 6.

The OR of premature ejaculation decreased with age being, in comparison with men aged $<=30$ years, 0.16 (95\% CI 0.05-0.50) in men aged $>70$ years.
Table 4.

Odds ratios (and corresponding 95\% confidence intervals) of any urinary symptom according to selected factors.

\begin{tabular}{|c|c|c|c|}
\hline & \multicolumn{2}{|c|}{ Any urinary symptoms } & \multirow[b]{2}{*}{ OR (95Cl\%) } \\
\hline & $\begin{array}{c}\text { No } \\
\mathbf{N}^{*} \%\end{array}$ & $\begin{array}{l}\text { Yes } \\
\mathbf{N} \%\end{array}$ & \\
\hline \multicolumn{4}{|l|}{ Age (years) } \\
\hline$\leq 30$ & $\begin{array}{c}51 \\
85.0\end{array}$ & $\begin{array}{c}9 \\
15.0\end{array}$ & $1^{\circ}$ \\
\hline $31-40$ & $\begin{array}{l}118 \\
69.0\end{array}$ & $\begin{array}{c}53 \\
31.0\end{array}$ & $2.31(1.03-5.19)$ \\
\hline $41-50$ & $\begin{array}{l}458 \\
61.9\end{array}$ & $\begin{array}{l}282 \\
38.1\end{array}$ & $2.92(1.39-6.11)$ \\
\hline $51-60$ & $\begin{array}{l}301 \\
44.3\end{array}$ & $\begin{array}{c}378 \\
55.7\end{array}$ & $5.12(2.44-10.75)$ \\
\hline $61-70$ & $\begin{array}{l}150 \\
32.1 \\
\end{array}$ & $\begin{array}{l}317 \\
67.9 \\
\end{array}$ & $7.82(3.68-16.74)$ \\
\hline$\geq 71$ & $\begin{array}{c}31 \\
18.0\end{array}$ & $\begin{array}{l}141 \\
82.0 \\
\end{array}$ & $17.02(7.36-39.33)$ \\
\hline \multicolumn{4}{|l|}{ BMI $\left(\mathrm{kg} / \mathrm{m}^{2}\right)$} \\
\hline$<25.0$ & $\begin{array}{l}491 \\
56.0 \\
\end{array}$ & $\begin{array}{l}386 \\
44.0 \\
\end{array}$ & $1^{\circ}$ \\
\hline$\geq 25.0$ & $\begin{array}{l}475 \\
42.8 \\
\end{array}$ & $\begin{array}{l}636 \\
57.3 \\
\end{array}$ & $1.35(1.12-1.64)$ \\
\hline \multicolumn{4}{|l|}{ Marital status } \\
\hline Never married & $\begin{array}{l}306 \\
61.6 \\
\end{array}$ & $\begin{array}{l}191 \\
38.4 \\
\end{array}$ & $1^{\circ}$ \\
\hline Married & $\begin{array}{l}741 \\
44.4 \\
\end{array}$ & $\begin{array}{c}927 \\
55.6 \\
\end{array}$ & $1.12(0.8-1.44)$ \\
\hline Divorced/vidower & $\begin{array}{c}17 \\
47.2 \\
\end{array}$ & $\begin{array}{c}19 \\
52.8 \\
\end{array}$ & $0.80(0.34-1.89)$ \\
\hline \multicolumn{4}{|c|}{ Any sexual dysfuncion } \\
\hline No & $\begin{array}{r}916 \\
52.9 \\
\end{array}$ & $\begin{array}{l}817 \\
47.1 \\
\end{array}$ & $1^{\circ}$ \\
\hline Yes & $\begin{array}{l}238 \\
36.8\end{array}$ & $\begin{array}{l}409 \\
63.2\end{array}$ & $1.60(1.29-1.98)$ \\
\hline \multicolumn{4}{|c|}{$\begin{array}{l}\text { *Sometimes, the sums do not add up the total due to missing values } \\
\text { 'Reference category } \\
\text { OR: odds ratio; Cl: confidence interval. Multivariate estimates including terms for the } \\
\text { above listed variables. }\end{array}$} \\
\hline
\end{tabular}

Table 5.

Frequency of sexual dysfunction according to age.

\begin{tabular}{|l|c|c|c|c|}
\hline & $\begin{array}{c}\text { Erectile } \\
\text { dysfunction }\end{array}$ & $\begin{array}{c}\text { Premature } \\
\text { ejaculation }\end{array}$ & $\begin{array}{c}\text { Hypoactive } \\
\text { sexual desire }\end{array}$ & $\begin{array}{c}\text { Any sexual } \\
\text { dysfunction }\end{array}$ \\
\cline { 2 - 5 } Age (years) & $\mathbf{N} \%$ & $\mathbf{N} \%$ & $\mathbf{N} \%$ & $\mathbf{N} \%$ \\
\hline$<=30$ & 6 & 10 & 2 & 18 \\
& 10.0 & 16.7 & 3.3 & 30.0 \\
\hline $31-40$ & 15 & 20 & 7 & 30 \\
& 8.8 & 11.79 & 4.1 & 22.8 \\
\hline $41-50$ & 52 & 55 & 39 & 127 \\
& 7.0 & 7.4 & 5.3 & 17.2 \\
\hline $51-60$ & 107 & 46 & 61 & 184 \\
& 15.8 & 6.8 & 9.0 & 27.1 \\
\hline $61-70$ & 122 & 35 & 49 & 181 \\
& 26.1 & 7.5 & 10.5 & 38.8 \\
\hline$>=71$ & 51 & 6 & 19 & 72 \\
& 29.7 & 3.5 & 11.2 & 41.9 \\
\hline Total & 370 & 178 & 182 & 647 \\
\multicolumn{5}{l|}{ Sometimes, the sums do not add up the total due to missing values. } \\
\hline \multicolumn{5}{|l|}{} \\
& 15.6 & 7.5 & 7.7 & 27.2 \\
\hline
\end{tabular}


Table 6.

Odds ratios (and corresponding 95\% confidence intervals) of premature ejaculation and erectile dysfunction according to selected factors.

\begin{tabular}{|c|c|c|c|c|c|c|}
\hline & \multicolumn{3}{|c|}{ Premature ejaculation } & \multicolumn{3}{|c|}{ Erectile dysfunction } \\
\hline & $\begin{array}{c}\text { No } \\
\mathbf{N}^{*} \%\end{array}$ & $\begin{array}{l}\text { Yes } \\
\mathrm{N} \%\end{array}$ & OR (95\%Cl) & $\begin{array}{c}\text { No } \\
\text { N \% }\end{array}$ & $\begin{array}{l}\text { Yes } \\
\mathrm{N} \%\end{array}$ & OR (95\%Cl) \\
\hline \multicolumn{7}{|l|}{ Age (years) } \\
\hline$<=30$ & $\begin{array}{c}50 \\
83.3\end{array}$ & $\begin{array}{c}10 \\
16.7\end{array}$ & $1^{\circ}$ & $\begin{array}{c}54 \\
90.0\end{array}$ & $\begin{array}{c}6 \\
10.0\end{array}$ & $1^{\circ}$ \\
\hline $31-40$ & $\begin{array}{l}151 \\
88.3\end{array}$ & $\begin{array}{c}20 \\
11.7\end{array}$ & $0.42(0.16-1.08)$ & $\begin{array}{l}156 \\
91.2\end{array}$ & $\begin{array}{l}15 \\
8.8\end{array}$ & $1.07(0.33-3.52)$ \\
\hline $41-50$ & $\begin{array}{l}685 \\
92.6\end{array}$ & $\begin{array}{l}55 \\
7.4\end{array}$ & $0.40(0.18-0.88)$ & $\begin{array}{l}688 \\
93.0\end{array}$ & $\begin{array}{l}52 \\
7.0\end{array}$ & $0.80(0.28-2.34)$ \\
\hline $51-60$ & $\begin{array}{l}633 \\
93.2\end{array}$ & $\begin{array}{l}46 \\
6.8\end{array}$ & $0.34(0.15-0.76)$ & $\begin{array}{l}572 \\
84.2\end{array}$ & $\begin{array}{l}107 \\
15.8\end{array}$ & $1.62(0.56-4.67)$ \\
\hline $61-70$ & $\begin{array}{l}432 \\
92.5\end{array}$ & $\begin{array}{l}35 \\
7.5 \\
\end{array}$ & $0.38(01.7-0.89)$ & $\begin{array}{l}345 \\
73.9 \\
\end{array}$ & $\begin{array}{c}122 \\
26.1 \\
\end{array}$ & $2.56(0.88-7.42)$ \\
\hline$>=71$ & $\begin{array}{l}166 \\
96.5\end{array}$ & $\begin{array}{c}6 \\
3.5\end{array}$ & $0.16(0.05-0.50)$ & $\begin{array}{c}121 \\
70.4 \\
\end{array}$ & $\begin{array}{c}51 \\
29.7 \\
\end{array}$ & $3.31(1.10-9.95)$ \\
\hline \multicolumn{7}{|l|}{$\overline{\text { BMI }\left(\mathrm{kg} / \mathrm{m}^{2}\right)}$} \\
\hline$>=24.9$ & $\begin{array}{l}806 \\
91.9\end{array}$ & $\begin{array}{l}71 \\
8.1 \\
\end{array}$ & $1^{\circ}$ & $\begin{array}{l}767 \\
87.5 \\
\end{array}$ & $\begin{array}{l}110 \\
12.5\end{array}$ & $1^{\circ}$ \\
\hline$>=25.0$ & $\begin{array}{l}1027 \\
92.4\end{array}$ & $\begin{array}{l}84 \\
7.6 \\
\end{array}$ & $0.96(0.68-1.95)$ & $\begin{array}{r}895 \\
80.6 \\
\end{array}$ & $\begin{array}{c}216 \\
19.4 \\
\end{array}$ & $1.25(0.96-1.63)$ \\
\hline \multicolumn{7}{|l|}{ Marital status } \\
\hline Never married & $\begin{array}{l}455 \\
91.6\end{array}$ & $\begin{array}{l}42 \\
8.5\end{array}$ & $1^{\circ}$ & $\begin{array}{l}443 \\
89.1\end{array}$ & $\begin{array}{c}54 \\
10.9\end{array}$ & $1^{\circ}$ \\
\hline Married & $\begin{array}{c}1541 \\
92.4\end{array}$ & $\begin{array}{l}127 \\
7.6\end{array}$ & $1.30(0.82-1.07)$ & $\begin{array}{l}1377 \\
82.6\end{array}$ & $\begin{array}{l}291 \\
17.5\end{array}$ & $0.84(0.58-1.21)$ \\
\hline Divorced/vidower & $\begin{array}{c}32 \\
100.0\end{array}$ & $\begin{array}{c}4 \\
0.0\end{array}$ & n.d. & $\begin{array}{c}26 \\
76.0\end{array}$ & $\begin{array}{c}10 \\
24.0\end{array}$ & $1.71(0.62-4.77)$ \\
\hline \multicolumn{7}{|l|}{ Urinary symtoms } \\
\hline No & $\begin{array}{c}1069 \\
92.6\end{array}$ & $\begin{array}{l}85 \\
7.4 \\
\end{array}$ & $1^{\circ}$ & $\begin{array}{c}1041 \\
90.2\end{array}$ & $\begin{array}{c}113 \\
9.8\end{array}$ & $1^{\circ}$ \\
\hline Yes & $\begin{array}{l}1133 \\
92.4\end{array}$ & $\begin{array}{l}93 \\
7.6\end{array}$ & $1.32(0.93-1.89)$ & $\begin{array}{l}969 \\
79.0\end{array}$ & $\begin{array}{l}257 \\
21.0 \\
\end{array}$ & $1.85(1.40-2.43)$ \\
\hline \multicolumn{7}{|c|}{ Erectile dysfunction } \\
\hline No & $\begin{array}{c}1863 \\
92.7\end{array}$ & $\begin{array}{l}147 \\
7.3\end{array}$ & $1^{\circ}$ & - & - & - \\
\hline Yes & $\begin{array}{l}339 \\
91.6 \\
\end{array}$ & $\begin{array}{l}31 \\
8.4\end{array}$ & $1.42(0.92-2.21)$ & - & - & - \\
\hline \multicolumn{7}{|c|}{ Premature ejaculation } \\
\hline No & - & - & - & $\begin{array}{l}1863 \\
84.6 \\
\end{array}$ & $\begin{array}{l}339 \\
15.4 \\
\end{array}$ & $1^{\circ}$ \\
\hline Yes & - & - & - & $\begin{array}{l}203 \\
42.1 \\
\end{array}$ & $\begin{array}{l}279 \\
58.0\end{array}$ & $1.45(0.94-2.23)$ \\
\hline \multicolumn{7}{|l|}{ Hypertension } \\
\hline No & $\begin{array}{c}1909 \\
92.4\end{array}$ & $\begin{array}{r}157 \\
7.6 \\
\end{array}$ & $1^{\circ}$ & $\begin{array}{r}1793 \\
86.8\end{array}$ & $\begin{array}{l}273 \\
13.2\end{array}$ & $1^{\circ}$ \\
\hline Yes & $\begin{array}{l}293 \\
93.3\end{array}$ & $\begin{array}{l}21 \\
6.7\end{array}$ & $0.88(0.53-1.49)$ & $\begin{array}{l}217 \\
69.1\end{array}$ & $\begin{array}{c}97 \\
30.9\end{array}$ & $1.66(1.21-2.26)$ \\
\hline \multicolumn{7}{|l|}{ Diabetes } \\
\hline No & $\begin{array}{l}2119 \\
92.4\end{array}$ & $\begin{array}{l}174 \\
7.6\end{array}$ & $1^{\circ}$ & $\begin{array}{l}1960 \\
85.5\end{array}$ & $\begin{array}{c}333 \\
14.5\end{array}$ & $1^{\circ}$ \\
\hline Yes & $\begin{array}{c}83 \\
95.4\end{array}$ & $\begin{array}{c}4 \\
4.6\end{array}$ & $0.57(0.20-1.62)$ & $\begin{array}{c}50 \\
57.5\end{array}$ & $\begin{array}{c}37 \\
42.5\end{array}$ & $2.37(1.45-3.88)$ \\
\hline $\begin{array}{l}\text { *Sometimes, the sum } \\
\text { 'Reference category } \\
\text { OR: odds ratio; Cl: con } \\
\text { Nd. Not determined. }\end{array}$ & $\begin{array}{l}\text { tadd up t } \\
\text { interval. }\end{array}$ & otal due & $\begin{array}{l}\text { missing values } \\
\text { timates including term }\end{array}$ & he above II & variable & \\
\hline
\end{tabular}

2.43)], hypertension [OR 1.66 $(95 \%$ CI 1,21-2,26)] and diabetes [OR 2.37 (95\%CI 1.45-3.88)] increased the risk of erectile dysfunction.

\section{Discussion}

Before discussing the results of this survey, potential limitations should be considered.

The major flaw of this study is that the study population were men voluntarily presenting to the

participating centers and physicians associated to the Italian Society of Urology (SIU).

The participating centers were not randomly identified among all members, so they cannot be considered representative of all Italian centers. However, they were well distributed over the main areas of the country and there were no marked differences in the results among centers in various large Italian areas, giving strong support to the consistency of the general results. Further, the prevalence of hypertension and diabetes and overweight were largely similar to the general Italian population.

For example the percentage of overweight and obese men was largely similar to that of the Italian population (9).

Finally, the participation rate was very high: for example the answers to the questions about sexuality were missing in a few number of men. Along this line, the patients presented voluntarily to the physician, so their answers to sensitive questions about sexual dysfunction should be truthful.

The strengths of the study included the fact that it provides information from a large series of men identified in all parts of Italy.

Despite the limitations, the results of this large survey gives a general picture of the burden of urological conditions in the Italian populations.

\section{Urinary symptoms}

First of all In the present study the self reported frequency of most

The OR of erectile dysfunction increased with age being, in comparison with men aged $<=30$ years, 3.31 (95\% CI1, 10-9.95) in men aged $>70$ years. Current any urinary symptoms [OR 1.85 (CI 1.40- common low urinary tract symptoms (LUTS) was about $50 \%$, a proportion largely similar to that reported in the Italian centers of EPIC study. In that study nocturia was the most prevalent LUTS (2). 
We confirm these findings. The frequency of urinary symptoms increased markedly with age being about 15\% among men aged 30 years or less, but $82 \%$ among those aged 71 or more.

This findings is consistent with other epidemiologic studies of LUTS conducted in men, which also showed that the prevalence of all symptoms increased linearly with age $(10,11)$.

Overweight/obesity increased the risk of urinary symptoms. In particular overweight /obesity increased the risk of urgency. This finding is consistent with data from other populations (12).

Interestingly concurrent sexual dysfunction increased the risk of urinary symptoms.

\section{Sexual dysfunction}

This study also give further data on the frequency of the main sexual dysfunctions in the Italian populations.

In the present survey the reported frequency of premature ejaculation was lower than previously reported among Italian men.

For example, the prevalence of premature ejaculation was of about $20 \%$ in a large survey of men attending a free andrologic consultation in about 200 Italian medical centers, in the 2001 (13).

This difference may be partly due to the fact that in the 2001 survey the mean age of participants was lower than in the present study. It has been suggested that diabetes decreased the risk of PE.

For example a decreased risk of PE was found in men with treated diabetes (OR 0.6, 95\% CI 0.5-0.8) in men attending a free andrologic consultation in 186 Italian medical centers, in the setting of a project focused on andrologic prevention in Italy (13). It is well known that diabetic patients may develop failure of emission, due both to neuropathic changes of the sympathetic fibers innervating the bladder neck and to aperistalsis of the vas deferens (14).

These changes act in opposition to the mechanism of $\mathrm{PE}$, so that it seems diabetes gives a protective effect against such condition In our study the estimated OR od EP was lower than unity in men reporting diabetes, but the finding was not statistically significant, possibly due to the limited number of diabetics.

With regard to erectile dysfunction, the present analysis confirm that ED is a common condition, particularly among older men. The estimated prevalence of the conditions reported in this study is largely consistent with the findings of a population based study conducted in Italy in the late ' 90 showing a prevalence of $\mathrm{ED}$ of about $12 \% 3$. Further this study confirms that diabetes, and hyperthension increased the risk of erectile dysfunction. A more interesting findings id the opportunity of analyzing in a large data set the association between urinary symptoms and ED. Some recent data have in fact linked ED risk with the presence of LUTS (15). We recorded if men suffered from several urinary symptoms: an association emerged between these symptoms and ED.

Finally, another interesting finding emerging from this survey is the fact that about $85 \%$ of subjects aged $>70$ year reported on or more PSA test life. This proportion however lowered to less than 70\% among men aged 51-
60 year. This finding is consistent with that reported in other countries. For example about $60 \%$ of US men aged 76 or older with no history of prostate cancer reported having had a PSA test in year before the interview (16). Otherwise semen analysis is uncommonly reported: less than $15 \%$ of men reported one or more semen analysis in life.

In conclusion, this large survey gives a picture of the burden of the more frequent urologic conditions offering useful information in order to focus preventive campaign.

\section{REFERENCES}

1. Robertson C, Link CL, Onel E, et al. The impact of lower urinary tract symptoms and comorbidities on quality of life: the BACH and UREPIK studies. BJU Int. 2007; 99:347-54.

2. Irwin DE, Milsom I, Hunskaar S, et al. Population-based survey of urinary incontinence, overactive bladder, and other lower urinary tract symptoms in five countries: results of the EPIC study. Eur Urol. 2006; 50:1306-14.

3. Parazzini F, Menchini Fabris F, Bortolotti A, et al. Frequency and determinants of erectile dysfunction in Italy. Eur Urol. 2000; 37:43-9.

4. Gruppo di lavoro AIOM-AIRTUM. I numeri del cancro in Italia 2016. Available at: http://www.registri-tumori.it/PDF/AIOM2016/I _numeri_del_cancro_2016.pdf (Last accessed 15 March 2017). 2016.

5. Litman HJ, McKinlay JB. The future magnitude of urological symptoms in the USA: projections using the Boston Area Community Health survey. BJU Int. 2007; 100:820-5.

6. NIH Consensus Conference. Impotence. NIH Consensus Development Panel on Impotence. JAMA. 1993; 270:83-90.

7. Abrams P, Cardozo L, Fall M, et al. The standardisation of terminology of lower urinary tract function: report from the Standardisation Sub-committee of the International Continence Society. Neurourol Urodyn. 2002; 21:167-78.

8. Baker NJ, Nelder JA. The GLIM System. Release 3. Oxford: Numerical Algorithms Group. 1978.

9. Gallus S, Colombo P, Scarpino V, et al. Overweight and obesity in Italian adults 2004, and an overview of trends since 1983. Eur J Clin Nutr. 2006; 60:1174-9.

10. Malmsten UG, Milsom I, Molander U, Norlen LJ. Urinary incontinence and lower urinary tract symptoms: an epidemiological study of men aged 45 to 99 years. J Urol. 1997; 158:1733-7.

11. Engstrom G, Walker-Engstrom ML, Loof L, Leppert J. Prevalence of three lower urinary tract symptoms in men-a population-based study. Fam Pract. 2003; 20:7-10.

12. Mondul AM, Giovannucci E, Platz EA. A prospective study of obesity, and the incidence and progression of lower urinary tract symptoms. J Urol. 2014; 191:715-21.

13. Basile Fasolo C, Mirone V, Gentile V, et al. Premature ejaculation: prevalence and associated conditions in a sample of 12,558 men attending the andrology prevention week 2001--a study of the Italian Society of Andrology (SIA). J Sex Med. 2005; 2:376-82.

14. Sexton WJ, Jarow JP. Effect of diabetes mellitus upon male reproductive function. Urology. 1997; 49:508-13.

15. Song J, Shao Q, Tian Y, Chen S. Lower urinary tract symptoms, 
erectile dysfunction, and their correlation in men aged 50 years and above: a cross-sectional survey in Beijing, China. Med Sci Monit. 2014; 20:2806-10.

16. Li J, Zhao G, Pollack LA, et al. Use of the prostate-specific anti- gen test among men aged 75 years or older in the United States: 2006 Behavioral Risk Factor Surveillance System. Prev Chronic Dis. 2010; 7(4). Available at : https://www.cdc.gov/pcd/issues//2010/jul/ pdf/09_0167.pdf. (Last access 15 March 2017). 2010.

\section{*Participating Centres:}

Abbate F (Caltagirone), Altomare M (Molfetta), Amici A (Roma), Anceschi C (Roma), Arena G (Cuneo), Artibani W (Verona), Avolio A (Ascoli Piceno), Bassi P (Roma), Battaglia M (Bari), Beatrici V (Pesaro-Fano), Beleggia F (Taranto), Bianchi G (Modena), Boccafoschi C (Alessandria), Bocciardi AM (Milano), Brausi M (Carpi), Brigante S (Brindisi), Bruschetta S (Messina), Buizza C (Busto Arsizio), Cafarelli A (Ancona), Caggiano S (Caserta), Canclini LP (Milano), Cappa M (Roma), Caraceni E (Civitanova Marche), Caravetta A (Acri), Carbone A (Latina), Carini M (Firenze), Carluccio G (Tricase), Catanzaro F (Cesano Boscone), Cavaliere A (Lecce), Cavalieri S (Negrar), Cecchi M (Lido Di Camaiore), Celia A (Bassano del Grappa), Chincoli S (Andria), Cicalese V (Avellino), Cisternino A (S. Giovanni Rotondo), Conti E (Sarzana), Corrada PL (Vizzolo Predabissi), Cosentino V (Catania), Cossu FM (Nuoro), Cusumano R (Roma), Cuzzocrea DE (Bologna), Dal Bianco M (Padova), Damiano R (Catanzaro), d'Anca M (Enna), D’Andrea R (Canistro), De Antoni (Udine), De Ceglie G (Cerignola), De Lisa A(Cagliari), Del Boca C (Cremona), De Martin M (Reggio di Calabria), De Siati M (Altamura), De Sio M (Napoli), De Zorzi L (Castelfranco Veneto), Defidio L (Roma), Di Clemente L (Coppito), Di Clemente L (Avezzano), Di Marco M (Roma), Di Martino M (Avellino), Di Stefano G (Ottaviano), Ditonno P (Bari), Di Trapani D (Palermo), Emili E (Imola), Fasolis G (Alba), Ferrando U (Torino), Ferrara V (Jesi), Ferrari G (Modena), Ficarra V (Udine), Fiorentino V (Lagonegro), Fischetti G (Roma), Frea B (Torino), Galli R (Bergamo), Galosi AB (Ancona), Gambarella Cherubino M (Mercogliano), Frattini A (Guastalla), Garbeglio A (Pordenone), Gentile V (Roma), Giulianelli R (Roma), Gontero P (Torino), Greco F (Roca di Neto), Greco U (Salerno), Gregori A (Garbagnate Milanese), Grisanti R (Sassuolo), Grosso G (Peschiera del Garda), Guizzardi F (Caltanisetta), Imperatore V (Napoli), Italiano E (Palermo), Ippolito C (Cona), Jungano R (Napoli), La Rocca L (Martina Franca), Laganà A (Tivoli), Leonardi R (Gravina di Catania), Lotesoriere O (Copertino), Lovisolo JA (Saronno), Lusuardi L (Bolzano), Maccatrozzo L (Treviso), Madonia M (Sassari), Maestroni UV (Parma), Magno C (Messina), Malossini G (Trento), Mammana G (Macerata), Manoni L (Pistoia), Marascia G (Chieti), Marchionni L (Roma), Martorana G (Bologna), Mastroeni F (Messina), Mearini E (Terni), Meneghini A (Santorso), Mensi M (Voghera), Merciai M (Oliveto Citra), Merlo F (Venezia Mestre), Minervini MS (Sondrio), Monesi G (Borgosesia) Montorsi F (Milano), Morelli E (Mirabella Eclano), Natali A (Firenze), Nigro GL (Crotone), Oliva G (Montepulciano), Paola Q (Sciacca), Pecoraro G (Isola Della Scala), Pennisi M (Catania), Perdonà S (Napoli), Pescione E (Napoli), Pompa P (Pescara), Ponchietti R (Siena), Porena M (Perugia), Porpiglia F (Orbassano), Porreca A (Abano Terme), Zito AR (Napoli), Raber M (Milano), Ranieri A (Lovere), Ranno S (Catania), Ricapito VD (Monopoli), Risi O (Treviglio), Rizzotto A (Viterbo), Rosa A (Verbano-Cusio-Ossola), Ruggiero G (Telese Terme), Russo G (S. Giorgio a Cremano), Saita A (Catania), Salvia G (Catania), Salzano L (Benevento), Sandri S (Magenta), Sanseverino R (Nocera Inferiore), Schiavone D (Rovigo), Scoffone C (Torino), Scognamiglio G (Castellamare Di Stabia), Schips L (Chieti), Selli C (Pisa), Sepe G (Mondragone), Simeone C (Brescia), Simonato A (Palermo), Sorrentino M (S. Maria Caupa Vetere), Striano S (Caserta) Tasso M (Brà), Tasso M (Tivoli), Tenaglia R (Chieti), Terrone C (Genova), Traficante A (Carbonara di Bari), Tralce L (Chiari), Trombetta C (Trieste), Tubaro A (Roma), Tufano A (Eboli), Tura M (Monza), Ventura F (Cosenza), Verbena A (Locri), Vespasiani G (Roma), Vicentini C (Teramo), Vita A (Potenza), Voce S (Ravenna), Volpe A (Novara), Xausa D (Feltre), Zarrelli G (Vercelli), Zaramella S (Ponderano), Zago T (Rho), Zattoni F (Padova), Zoccali C (Lamezia Terme). Data analysis: Ricci E, Esposito G (Milano).

\section{Correspondence}

Vincenzo Mirone, MD

Università degli Studi di Napoli Federico II, UOC di Urologia della A.O.U. Federico II, Napoli, Italy

Roberto Carone, MD

Università degli Studi di Torino, Struttura Complessa di Neuro-Urologia A.O.U. Città della Salute

e della Scienza, Torino, Italy

Giuseppe Carrieri, MD

Dipartimento Nefro/Urologico Clinica Urologica e Centro Trapianti di Rene,

Università degli Studi di Foggia, Foggia, Italy

Elisabetta Costantini, MD

Sezione di Urologia Femminile, Funzionale e di Chirurgia Urologica

Mini-invasiva. Dipartimento di scienze chirurgiche e biomedicali

Università di Perugia, Perugia, Italy

Giuseppe Morgia, MD

Università degli Studi di Catania Presidio Ospedaliero Policlinico

Catania, Italy

Giuseppe Mario Ludovico, MD

Struttura Complessa Urologia Ospedale "Miulli", Acquaviva delle Fonti, Italy

Donata Villari, MD

Università degli Studi di Firenze, SOD Chirurgia Urologica Mini-invasiva

e dei Trapianti Azienda Mista Universitaria Ospedaliera Careggi

Firenze, Italy

Fabio Parazzini, MD (Corresponding Author)

fabio.parazzini@unimi.it

Dipartimento di Scienze Cliniche e di Comunità, Università di Milano,

Fondazione IRCCS Ca' Granda Ospedale Maggiore Policlinico

Via Commenda 12, 20122 Milano, Italy 